wonted ability. I have the honour to remain, Sir, yours very respectfully,

J. BEDINGEIELD.

Stowmarket, Jan. 26th, 1836.

\section{EULOGISTS OF RHUBARB HALL.}

To the Editor of The Lancet.

Sin,-In Rorlerick's joirnal of last week is printed a document healed "Priti sit of the Students of Guy's Hospital against the late proceedings at the Crown-and-Anchor" said by Roderick to have attached to it the signatures of 9.4 of the stulents of that hospital :* now Sir, I think it right that you should be acquainted with the hole-andcorner manner in which this "protest" has been got up by its promoters, Messieurs H. C. Muggand and J. Bent. These buzzing busy bodies, who attend to every person's affairs but their own,-or they might perhaps, ere this, have been enabled, with the aid of a little favour at court, to pass the ordeal at Rhubarb Hall, - have got up this document expressly to court that very favour. I am sorry that their abilities and diligence need it. In that document they term the 94 who have signed it, a "large majority" of the students of Guy's, but to say the least of it, this is untrue. They also call the proceedings of that meeting " ill jurged and violent," and state that they were "characterized throughout by party violence," which is notoriously false. Sow, Sir, from the admission of two individuals whose names are attached to that document. I can assert that neicher of them was present at the meeting; consequently they rely on the reports of others in making the allegations to which they have attached their narnes; and 1 believe that very many more, if not the majority of those who signed that paper, were not present at that meeting; and 1 can positively say that not a few repent having signed it; I have learnt this from their own lips. In addition to this, I may remark, that Messrs. Muggand and Benit induced several juvenile pupils (fresh from the country) to sign the paper in question, solely on the ground that they could not do wroug by following in the footsteps of their seniors. These young gentlemen will learn wisdom from experience. I refrain from saying any thing more on the subject of this "protest," than that we are greatly surprised in the Borough that any medical students, of whatever party, should be found

* 94 does not form a fourth part of the number of 400, which Guy's Hospital used to bonst that it fostered per session. No wonder that medical reform is a repugnant topic in some nooks in that quarter. to connive at ani applaud the ungentlomanly nod unworthy manner in which the worshipful examiner at Apothecaries' Hall acted when he questioned and rejected $M r$. Smith. I am, Sir, yours very respectfully,

A GuY's Mospital Srudent. Guy's Hospital, Feb. 16th, 1836.

Note From Mr. Watrs. - To the Editor. -Sir,-On reading over my letter in your excellent publication, I heg to say that I committed a quite unintentional mistake, when I stated that I had attended nine parishes for eighteen years. Several of them I have so attended, and others in intermediate spaces of time. This was what $I$ de. signed to express. At the same time $I$ heg to assure you and my professional brethren that my object in giving publicity to the Wheatenhurst Poor-Law-Union proceeding, was not with the slightest intention of doing Mr. Moseley any professional injury, but to poirt out the system as one which is degrading to the profession, and injurious to the poor. I am, Sir, your obedient servant,

Frampton-upon-Severn,

Thomas WatTs.

Feb. 17,1836 .

Coroner for Aberystwyth. I t the Ealitor.-Sir,-Seeing by a letter inserted in The LaNos of Feb. 13th, that you are anxious to ascertain the number of medical coroners in England and Wales, I ber to state that the Coroner tor Aberystwyth, Cardiganshire, is Rice Williams, Fsq., a medical gentleman who has filled the office of Coroner in that town for a leagth of time. I am, Sir, yours, obediently,

A Student of Medicine.

\section{MEDICAL WITNESSES BILL.}

To the Eclitor. - Sir, I enclose you a copy of a Petition to the House of Commons, prepared at a meeting of the committee of the "Bucks Medical Association," lately held at Aylesbury. It is now in course of signature, and will shortly be ready for presentation. The support of its prayer will be carnestly requested of the county and borough members. I have the honour to be, Sir, your obedient servant,

Aylesbury, Feb. 15, 1836.

Robert Ceely, Hon. Sec.

*** The petitioners draw the attention of the House to the fact that a coroner's inquest, without efficient inedical evidence, can be but an empty form, and is, consequently, a source of useless expense, and 